\title{
INDUKSI UMBI MIKRO DAN REGENERASI TUNAS LANGSUNG TANAMAN KENTANG DATARAN MEDIUM PADA BEBERAPA JENIS AUKSIN DAN KONSENTRASI SUKROSA YANG BERBEDA
}

\author{
Direct microtuberization and in vitro shoot regeneration of medium land potato \\ using different auxins and various level of sucrose
}

\author{
Sepdian Luri Asmono* dan Vega Kartika Sari \\ Jurusan Produksi Pertanian Politeknik Negeri Jember, \\ JL. Mastrip PO Box164 Jember \\ *Alamat korespondensi : sepdian@polije.ac.id
}

\begin{abstract}
ABSTRAK
Pengambangan tanaman kentang di dataran medium atau rendah sangat diperlukan untuk memperluas areal penanamannya. Oleh sebab itu harus ditunjang dengan metode kultur in vitro untuk memproduksi umbi dan tunas mikro kentang dan secara teknis diperlukan asupan zat pengatur tumbuh dan konsentrasi sukrosa yang cocok. Penelitian ini bertujuan untuk mengetahui pengaruh dari beberapa jenis auksin dan beberapa level sukrosa terhadap pembentukan umbi mikro dan regenerasi tunas kentang DTO-28 dan Desiree, serta mengetahui jenis auksin terbaik dan konsentrasi sukrosa. Penelitian ini dilaksanakan selama 4 bulan dan disusun menggunakan Rancangan Acak Lengkap Faktorial dengan 5 ulangan. Faktor pertama ialah kultivar kentang (DTO-28 dan Desiree). Faktor kedua ialah auksin (IAA, IBA, NAA) dan faktor ketiga ialah konsentrasi sukrosa yang terdiri atas tiga taraf $(90 \mathrm{~g} / \mathrm{l}, 120 \mathrm{~g} / \mathrm{l}$, $150 \mathrm{~g} / \mathrm{l})$. Pengamatan dilakukan terhadap pembentukan umbi serta pertumbuhan tunas. Hasil penelitian ini menunjukkan bahwa semakin tinggi konsentrasi sukrosa akan memacu pembentukan umbi mikro tetapi dilain hal mempengaruhi pembentukan dan pertumbuhan tunas. Perlakuan yang menggunakan 0,25 ppm NAA + $150 \mathrm{~g} / \mathrm{l}$ sukrosa mampu memunculkan umbi pada 22 HST dengan rata-rata 2,4 umbi/planlet. Selain itu, penggunaan $90 \mathrm{~g} / 1$ sukrosa memberikan jumlah tunas terbanyak yaitu rata-rata 5,27 tunas dengan panjang rata-rata $4,70 \mathrm{~cm}$.
\end{abstract}

Kata kunci: kentang, sukrosa, auksin, kultivar desiree dan DTO-28

\begin{abstract}
Potato cultivation on medium or low land is needed to expand the planting area. It must be supported by an in vitro culture method to produce microtuber and shoots and technically a growth regulator and a suitable sucrose concentration are needed. This study aims to determine the effect of several types of auxin and different level ofsucrose on micro tuber formation and shoots regeneration of DTO-28 and Desiree potato. This study was conducted for 4 months and was compiled using Factorial Completely Randomized Design with 5 replications. The first treatment factor is potato cultivars (DTO-28 and Desiree). The second factor is auxin (IAA, IBA, NAA) and the third factor is three levels of sucrose $(90 \mathrm{~g} / \mathrm{l}, 120 \mathrm{~g} / \mathrm{l}, 150 \mathrm{~g} / \mathrm{l})$. Observations were made on tuber formation and shoot growth. The results of this study indicate that the higher the concentration of sucrose will stimulate the formation of micro tuber but on the other hand it affects the formation and growth of shoots. The treatment using 0.25 ppm NAA + $150 \mathrm{~g} / \mathrm{l}$ sucrose was able to raise tubers at $22 \mathrm{HST}$ with an average of 2.4 tubers/ plantlets. In addition, the use of $90 \mathrm{~g} / \mathrm{l}$ sucrose gave the highest number of shoots, which averaged 5.27 shoots with an average length of $4.70 \mathrm{~cm}$.
\end{abstract}

Keywords : potato, sucrose, auxin, desiree and DTO-28 cultivars

\section{PENDAHULUAN}

Upaya peningkatan produksi kentang nasional sebaiknya tidak hanya dilakukan pada daerah dataran tinggi saja, tetapi juga pada daerah dataran yang lebih rendah. Ada beberapa kentang dataran medium dan rendah yang sudah dikembangkan di Indonesia dan hasilnya juga tidak kalah dengan kentang dataran tinggi. Menurut Handayani dan Sofiari (2011), beberapa daerah di Jawa Tengah, Yogyakarta, dan Sumatra Barat pernah mengembangkan 
kentang dataran medium. Hasil penelitian yang dilakukan Damiri dan Sugandi (2016), menunjukkan bahwa kentang dataran medium yang ditanam di daerah Rejang Lebong Bengkulu mampu memberikan hasil rata-rata antara 15,5-16 ton/ha. Salah satau kultivar kentang dataran medium adalah DTO-28 yang mampu menghasilkan 31,1 ton/ha di daerah Bali (Samadi, 2007). Selain itu ada pula kentang Desiree yang disebut juga dengan Kentang Merah yang baik untuk kesehatan karena mengandung antioksidan tinggi (Lachman et al., 2005).

Pengembangan kualitas kentang dataran medium menjadi hal yang penting untuk meningkatkan hasil produksinya. Salah satu cara untuk mengupayakan hal tersebut adalah dengan teknologi produksi bibit dari planlet atau umbi mikro (G0) melalui teknik kultur in vitro. Ada beberapa faktor yang harus dipertimbangkan dalam menginduksi dan menumbuhkan umbi mikro kentang, yaitu zat pengatur tumbuh dan sukrosa. Zat pengatur tumbuh (ZPT) berperan penting dalam pembentukan umbi mikro (Kaur et al., 2014). Menurut Roumeliotis et al. (2012), hormon auksin dapat memacu pembentukan umbi mikro kentang dan berpengaruh terhadap pertumbuhan jumlah dan berat segar. Selain itu, Iman et al., (2016) juga menyatakan bahwa konsentrasi sukrosa dalam media MS mempengaruhi pembentukan umbi. Berdasarkan hal tersebut, penelitian ini bertujuan untuk mengetahui pengaruh dari beberapa jenis auksin dan sukrosa terhadap pembentukan umbi mikro dan regenerasi tunas kentang DTO-28 dan Desiree, serta mengetahui jenis auksin terbaik dan konsentrasi sukrosa yang optimal.

\section{METODE PENELITIAN}

Penelitian ini menggunakan bahan planlet kentang Desiree dan DTO-28 sebagai eksplan. Serta menggunakan media dasar 1/2 MS (Purwanto dkk., 2007) dengan penambahan sukrosa dan beberapa jenis auksin seperti 0,25 ppm IAA (Indole-3acetic acid), 0,25 ppm IBA (Indole-3butyric acid) dan 0,25 ppm NAA (1Naphthaleneacetic acid).

Metode percobaan menggunakan Rancangan Acak Kelompok Faktorial dengan 3 faktor. Faktor pertama meliputi 2 kultivar kentang yaitu DTO-28 dan Desiree, faktor kedua meliputi IAA, IBA dan NAA. Faktor ketiga meliputi 90g/l, 120g/l, 150g/1 sukrosa. Terdapat 18 kombinasi perlakuan dengan 5 kali ulangan.

Penelitian ini dilaksanakan dalam 1 kali tahapan kultur selama 4 bulan. Eksplan dipotong $\pm 2 \mathrm{~cm}$ (terdapat 2 mata tunas) kemudian dikulturkan pada media perlakuan dan dilakukan pengamatan terhadap variabel penelitian yang meliputi: persentase pembentukan umbi (\%); waktu inisiasi umbi mikro (HST); jumlah umbi mikro; bobot segar umbi mikro (mg); serta 
jumlah dan panjang tunas (cm).

presentase terendah terlihat pada sukrosa Pengamatan dilakukan pada akhir $90 \mathrm{~g} / \mathrm{l}$.

penelitian (120 HST), kecuali pada

Gambar 1. menunjukkan bahwa pengamatan terhadap kemunculan umbi diamati setiap hari. Data pengamatan dianalisis menggunakan ANOVA dan dilanjutkan dengan uji DMRT (Duncan's Multiple Range Test) pada taraf $p=5 \%$.

\section{HASIL DAN PEMBAHASAN}

\section{Persentase pembentukan umbi}

Kultivar DTO-28 memberikan respon terbaik terhadap pembentukan umbi mikro daripada Kultivar Desiree. Data analisis pada Gambar 1 menunjukkan bahwa persentase pembentukan umbi tertinggi pada media perlakuan dengan penambahan sukrosa $120 \mathrm{~g} / \mathrm{l}$ dan $150 \mathrm{~g} / \mathrm{l}$, sedangkan sukrosa mengambil peranan penting terhadap inisiasi umbi mikro. Sonnewald dan Sonnewald (2014), menyatakan bahwa sukrosa merupakan salah satu prasyarat untuk proses kemunculan umbi mikro kentang. Beberapa jenis auksin tidak berpengaruh nyata dalam pembentukan umbi, tetapi diduga auksin berperan dalam pembentukan stolon pada planlet kentang. Liao (2011), menyatakan bahwa biosintesis auksin terjadi pada ujung stolon. Lebih lanjut Roumeliotis et al. (2012) menyatakan bahwa peningkatan auksin pada ujung stolon kentang berhubungan dengan pembentukan umbi kentang.

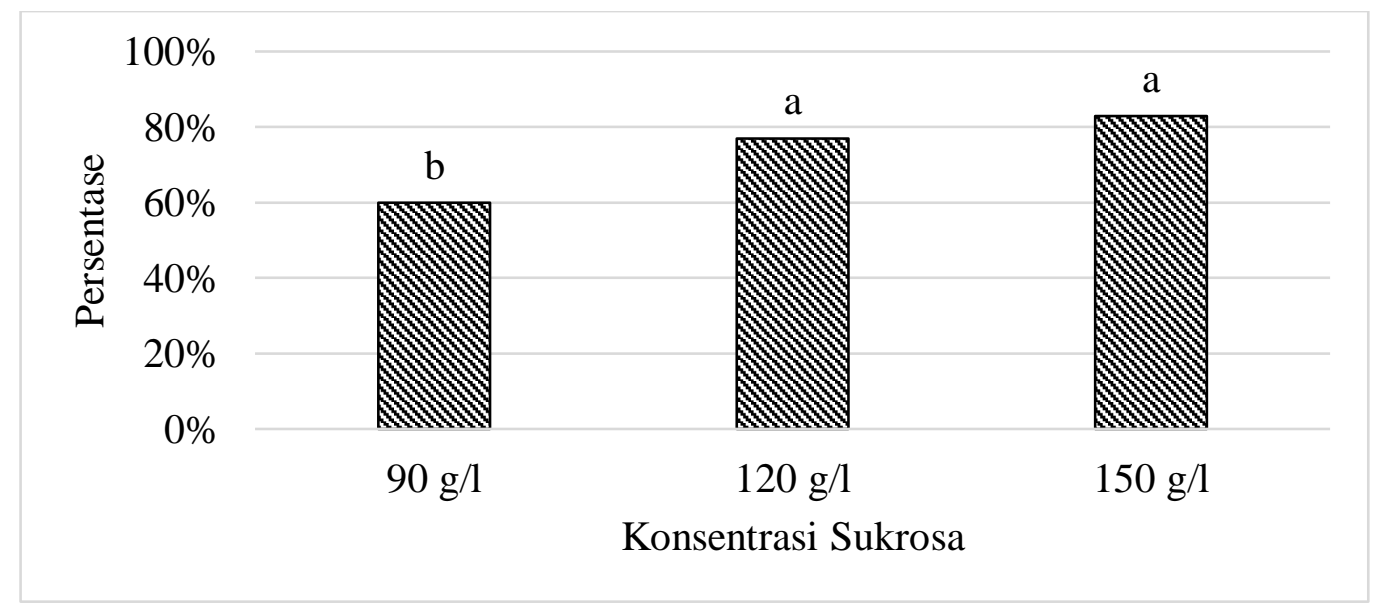

Gambar 1. Persentase pembentukan umbi mikro pada konsentrasi sukrosa yang berbeda 
Tabel 1. Waktu inisiasi (HST) umbi mikro kultivar DTO-28 dan Desiree dari perlakuan jenis auksin dan beberapa konsentrasi sukrosa

\begin{tabular}{cclllllll}
\hline \multicolumn{2}{c}{ Kultivar } & \multicolumn{3}{c}{ Auksin $(0,25 \mathrm{ppm})$} & \multicolumn{3}{c}{ Konsentrasi Sukrosa } \\
\hline DTO-28 & 40,6 & $\mathrm{~b}$ & IAA & 62,37 & $\mathrm{a}$ & $90 \mathrm{~g} / \mathrm{l}$ & 57,53 & $\mathrm{~A}$ \\
Desiree & 64,6 & $\mathrm{a}$ & IBA & 50,03 & $\mathrm{ab}$ & $120 \mathrm{~g} / \mathrm{l}$ & 58,13 & $\mathrm{~A}$ \\
& & & NAA & 45,37 & $\mathrm{~b}$ & $150 \mathrm{~g} / \mathrm{l}$ & 42,10 & $\mathrm{~B}$ \\
\hline
\end{tabular}

Keterangan: Angka-angka yang diikuti huruf yang sama pada kolom yang sama menunjukkan hasil yang tidak berbeda nyata berdasarkan uji DMRT pada taraf $p=5 \%$.

\section{Waktu inisiasi umbi mikro}

Respon terhadap kemunculan umbi sangat dipengaruhi oleh jenis auksin, sukrosa serta kultivar. Pada Tabel 1 tertera bahwa kemunculan umbi lebih cepat $(40,6$ HST) terlihat dari Kultivar DTO-28. Sukrosa pada konsentrasi 150g/l juga memberikan pengaruh terbaik karena ratarata kemunculan umbi pada 42,10 HST. Sedangkan pada konsentrasi yang lebih rendah menunjukkan kemunculan umbi lebih lambat. Antar jenis auksin pada konsentrasi yang sama $(0,25 \mathrm{mg} / \mathrm{l})$ juga memberikan pengaruh yang berbeda nyata. Tabel 1 menunjukkan bahwa NAA merupakan jenis auksin yang memberikan pengaruh terbaik, karena mampu memacu inisiasi umbi mikro lebih cepat yaitu pada 45,37 HST, daripada perlakuan yang menggunakan IAA dan IBA.

Hasil penelitian yang telah dilakukan Koleva et al. (2012) juga menunjukkan bahwa BAP yang dikombinasikan dengan NAA lebih memacu pembentukan umbi mikro daripada IAA. IAA merupakan hormon alami dan diduga akan meningkat konsentrasinya jika ditambahkan IAA eksogen, dan menurut Sonnewald and Sonnewald (2014) konsentrasi IAA yang tinggi akan menghambat pembentukan stolon dan umbi mikro.

\section{Jumlah umbi mikro}

Hasil uji Duncan pada Tabel 2 terlihat bahwa NAA memberikan pengaruh yang terbaik dan berbeda nyata dengan jenis auksin lainnya untuk jumlah umbi mikro walapun rata-rata jumlah umbi mikro yang terbentuk 1,48 umbi mikro per eksplan. Selain itu pada Tabel 2 juga terlihat bahwa jumlah umbi terbanyak terdapat pada media perlakuan yang mengandung $150 \mathrm{~g} / \mathrm{l}$ sukrosa.

Jenis auksin memiliki karakteristik tersendiri seperti yang terlihat pada IAA yang rata-rata jumlah umbi mikronya paling sedikit yaitu 0,48 umbi mikro per eksplan. IAA tersedia juga dalam bentuk endogen yang disintesis pada ujung tunas dan mempengaruhi dominansi apikal. Akumulasi IAA dari media diduga menghambat percabangan untuk pembentukan stolon. Menurut Pasare et al. (2013), percabangan stolon memacu pembentukan umbi mikro 
Tabel 2. Jumlah umbi mikro kultivar DTO-28 dan Desiree dari perlakuan jenis auksin dan beberapa konsentrasi sukrosa

\begin{tabular}{ccccrc}
\hline \multicolumn{2}{c}{ Kultivar } & \multicolumn{2}{c}{ Auksin $(0,25 \mathrm{ppm})$} & \multicolumn{2}{c}{ Konsentrasi Sukrosa } \\
\hline DTO-28 & $1,02 \mathrm{a}$ & IAA & $0,48 \mathrm{~b}$ & $90 \mathrm{~g} / \mathrm{l}$ & $0,68 \mathrm{~b}$ \\
Desiree & $0,74 \mathrm{~b}$ & IBA & $0,68 \mathrm{~b}$ & $120 \mathrm{~g} / 1$ & $0,72 \mathrm{~b}$ \\
& & NAA & $1,48 \mathrm{a}$ & $150 \mathrm{~g} / 1$ & $1,25 \mathrm{a}$ \\
\hline
\end{tabular}

Keterangan: Angka-angka yang diikuti oleh huruf yang sama pada kolom yang sama berarti berbeda tidak nyata berdasarkan uji $D M R T$ pada taraf $p=5 \%$.

Tabel 3. Bobot segar (mg) umbi mikrokultivar DTO-28 dan Desiree dari perlakuan jenis auksin dan beberapa konsentrasi sukrosa

\begin{tabular}{rrrrrr}
\hline \multicolumn{2}{c}{ Kultivar } & \multicolumn{2}{c}{ Auksin $(0,25 \mathrm{ppm})$} & \multicolumn{2}{c}{ Konsentrasi Sukrosa } \\
\hline DTO-28 & $3,82 \mathrm{a}$ & IAA & $1,60 \mathrm{~b}$ & $90 \mathrm{~g} / 1$ & $2,80 \mathrm{~b}$ \\
Desiree & $1,20 \mathrm{~b}$ & IBA & $2,16 \mathrm{~b}$ & $120 \mathrm{~g} / 1$ & $2,40 \mathrm{~b}$ \\
& & NAA & $3,78 \mathrm{a}$ & $150 \mathrm{~g} / 1$ & $2,34 \mathrm{~b}$ \\
\hline
\end{tabular}

Keterangan: Angka-angka yang diikuti oleh huruf yang sama pada kolom yang sama berarti berbeda tidak nyata berdasarkan uji $D M R T$ pada taraf $p=5 \%$.

Konsentrasi sukrosa yang terbaik untuk induksi jumlah umbi mikro kentang ialah pada $150 \mathrm{~g} / \mathrm{l}$. Hal tersebut sesuai penyataan Koleva et al. (2012) bahwa konsentrasi sukrosa yang optimum diduga berperan sebagai sinyal induksi yang mengakibatkan akumulasi pati, sehingga meningkatkan terbentuknya umbi mikro.

\section{Bobot segar umbi mikro}

Berdasarkan uji Duncan pada Tabel 3. kultivar dan jenis auksin berpengaruh nyata terhadap bobot segar umbi dan antar konsentrasi sukrosa tidak menunjukkan perbedaan yang nyata.

Kultivar DTO-28 lebih responsif terhadap zat pengatur tumbuh dan sukrosa yang diberikan, karena menghasilkan bobot segar lebih baik daripada kultivar Desiree. Pada penelitian yang dilakukan Alsulaiman (2011) menyatakan bahwa kemampuan respon setiap kultivar kentang berbeda beda tergantung dari media dan eksplan yang digunakan.

NAA juga berperan dalam pertambahan bobot segar umbi mikro. Diduga karakteristik yang NAA lebih meningkatkan proliferasi dan volume sel setelah umbi mikro terbentuk, sehingga terjadi peningkatan biomasa umbi (Romanov et al., 2000). Selain itu NAA juga meningkatkan elastisitas dinding sel sehingga memungkinkan nutrisi dan sukrosa masuk ke dalam sel (Kumlay and Ercisli, 2015). Sukrosa tidak berpengaruh nyata dalam bobot segar umbi, karena menurut $\mathrm{Yu}$ et al. (2000) berperan dalam proses inisiasi awal umbi mikro.

\section{Jumlah tunas}

Data analisis menunjukkan bahwa kultivar, jenis auksin, konsentrasi sukrosa serta interaksinya berbeda sangat nyata terhadap jumlah tunas. Kultivar DTO-28 
lebih responsif terhadap media perlakuan dalam proses pembentukan tunas daripada kultivar Desiree. Selain itu terlihat juga bahwa NAA berpengaruh nyata dalam memacu pembentukan tunas dan semakin tinggi konsentrasi sukrosa ternyata menghambat pembentukan tunas. Terlihat pada Tabel 4, jumlah tunas tertinggi pada sukrosa 90g/l dengan rata-rata 5,27 tunas per eksplan, sedangkan jumlah tunas semakin menurun pada konsentrasi $150 \mathrm{~g} / 1$ dengan rata-rata 1,90 tunas per eksplan.

Tabel 4. Jumlah tunas kultivar DTO-28 dan Desiree dari pengaruh tunggal jenis auksin dan beberapa konsentrasi sukrosa

\begin{tabular}{ccccrc}
\hline \multicolumn{3}{c}{ Kultivar } & \multicolumn{2}{c}{ Auksin $(0,25 \mathrm{ppm})$} & \multicolumn{2}{c}{ Konsentrasi Sukrosa } \\
\hline DTO-28 & $4,56 \mathrm{a}$ & IAA & $2,23 \mathrm{c}$ & $90 \mathrm{~g} / 1 \mathrm{5,27} \mathrm{a}$ \\
Desiree & $1,89 \mathrm{~b}$ & IBA & $2,80 \mathrm{~b}$ & $120 \mathrm{~g} / 1$ & $2,50 \mathrm{~b}$ \\
& & NAA & $4,63 \mathrm{a}$ & $150 \mathrm{~g} / 1$ & $1,90 \mathrm{c}$ \\
\hline
\end{tabular}

Keterangan: Angka-angka yang diikuti oleh huruf yang sama pada kolom yang sama berarti berbeda tidak nyata berdasarkan uji DMRT pada taraf $p=5 \%$.

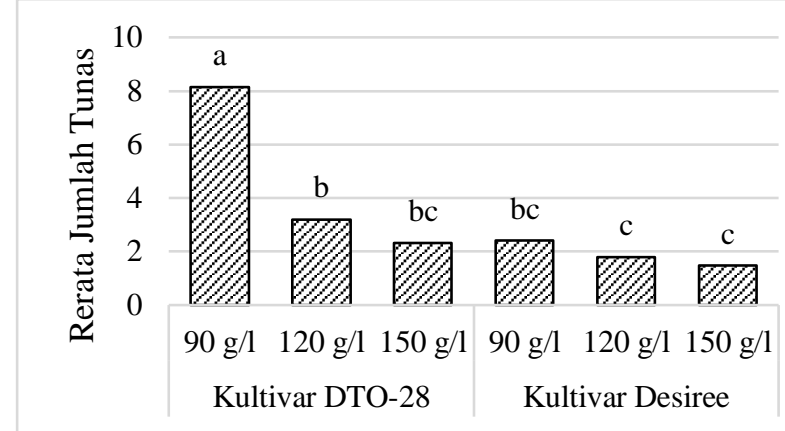

a

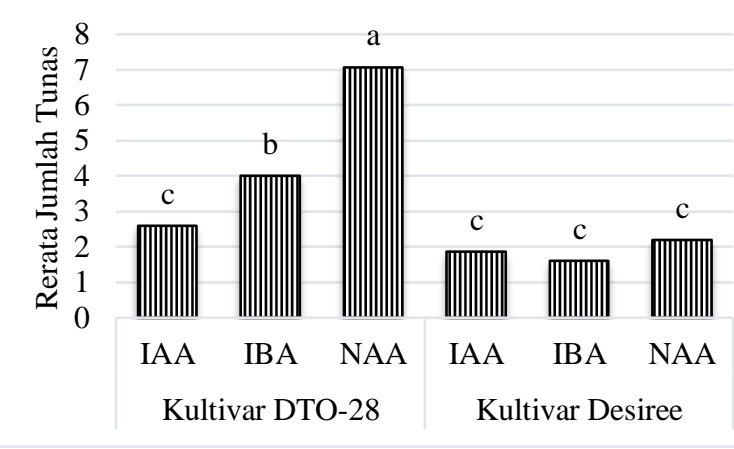

b

Keterangan: Angka-angka yang diikuti oleh huruf yang sama berarti berbeda tidak nyata berdasarkan uji DMRT pada taraf $p=5 \%$.

Gambar 2. Jumlah tunas hasil pengaruh interaksi antara a)Kultivar dan sukrosa; b) Kultivar dan auksin

Data hasil interaksi antara kultivar dengan sukrosa maupun auksin menunjukkan bahwa kultivar DTO-28 menghasilkan tunas lebih banyak. Pada Gambar 2a, menunjukkan rata-rata jumlah tunas pada sukrosa 90g/l lebih banyak daripada konsentrasi sukrosa lainnya. Semakin tinggi konsentrasi sukrosa mampu menghambat pembentukan tunas, tetapi dari hasil sebelumnya yaitu Tabel 2. justru memacu pembentukan umbi mikro.

Peran NAA juga terlihat lebih baik daripada IAA atau IBA dalam membentuk tunas. Berdasarkan Gambar 3, interaksi antara auksin dan sukrosa menunjukkan pengaruh yang sangat nyata. Interaksi terbaik terjadi pada NAA dengan 90g/l sukrosa yang menghasilkan rata-rata 9,4 tunas per eksplan. 
Interaksi dari ketiga faktor yang diujikan juga menunjukkan perbedaan yang sangat nyata pada rerata jumlah tunas, terlihat pada Gambar 4. bahwa Kultivar DTO-28 yang dikulturkan pada media 1/2 MS + 0,25 mg/l NAA+ $90 \mathrm{~g} / 1$ sukrosa memiliki tunas terbanyak dengan rata-rata
15,8 tunas per eksplan. Pengaruh konsentrasi sukrosa yang tinggi diduga meningkatkan tekanan osmotik sehingga memacu stress dan hormon penghambat tunas pada planlet dan mempengaruhi pembentukan tunas. Tetapi stress yang

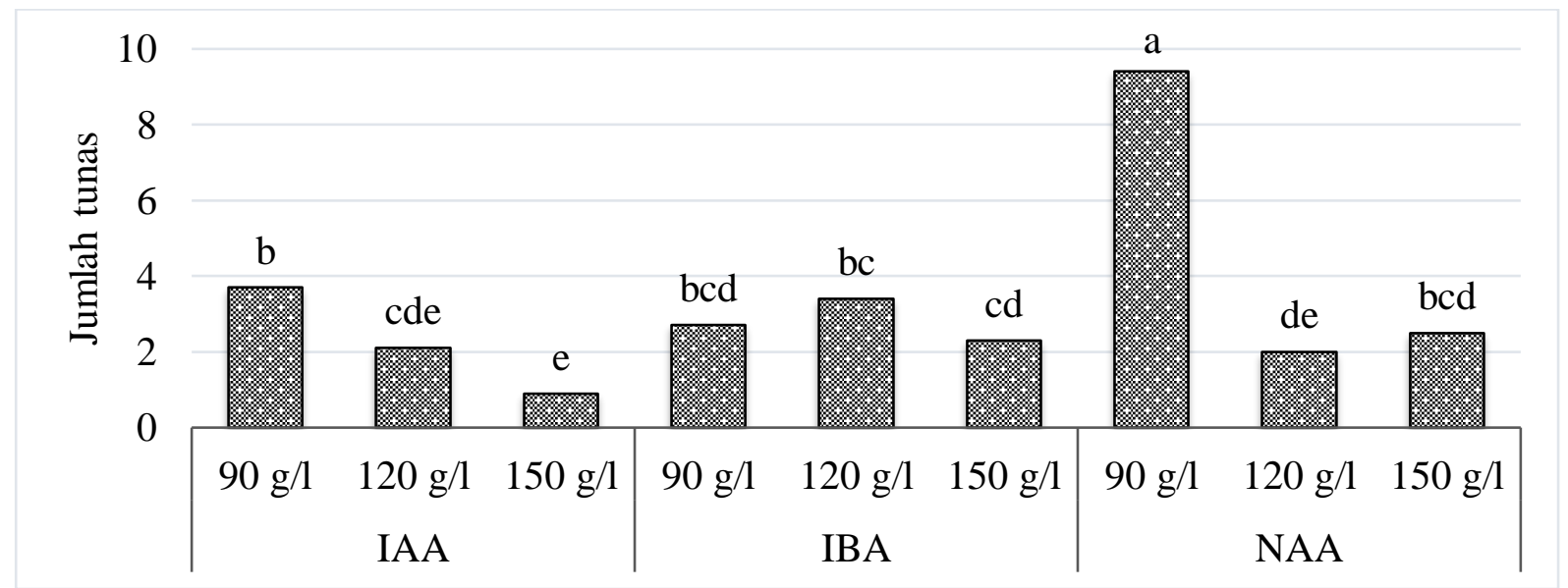

Keterangan: Angka-angka yang diikuti oleh huruf yang sama berarti berbeda tidak nyata berdasarkan uji $D M R T$ pada taraf $p=5 \%$.

Gambar 3. Grafik jumlah tunas hasil pengaruh interaksi antara sukrosa dan auksin

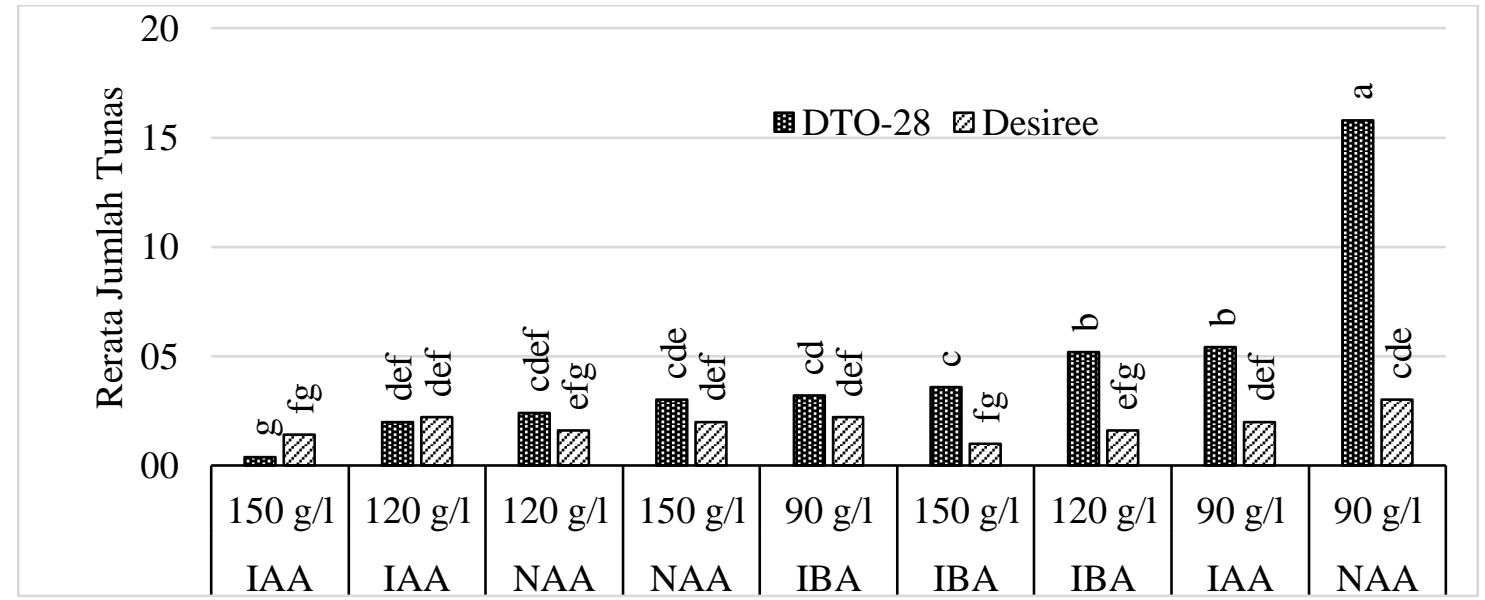

Keterangan: Angka-angka yang diikuti oleh huruf yang sama berarti berbeda tidak nyata berdasarkan uji DMRT pada taraf $p=5 \%$.

Gambar 4. Jumlah tunas hasil pengaruh interaksi antara kultivar, sukrosa dan auksin ditimbulkan tersebut justru mampu (2008), membuktikan bahwa konsentrasi memacu pembentukan umbi mikro (Gaafar sukrosa yang tinggi meningkatkan tekanan et al., 2015). Pada penelitian Skrzypek et al. 
p-ISSN: 1410-0029; e-ISSN2549-6786

Agrin Vol. 23, No. 1, April 2019

osmotik dan menghambat regenerasi tunas kalus kentang.

\section{Panjang tunas}

Data analisis panjang tunas menunjukkan bahwa kultivar, jenis auksin dan konsentrasi sukrosa secara tunggal berpengaruh nyata terhadap panjang tunas. interaksi antara kultivar dan auksin berpengaruh nyata terhadap panjang tunas. Hasil uji lanjut Duncan tertera pada Tabel 5 dan Gambar 5.

Dari data pengamatan Kultivar DTO28 memiliki tunas lebih panjang daripada Desiree. Sedangkan NAA dan IAA Data analisis juga menunjukkan bahwa

Tabel 5. Panjang tunas (cm) kultivar DTO-28 dan Desiree dari pengaruh tunggal jenis Auksin dan beberapa konsentrasi sukrosa

\begin{tabular}{ccccccc}
\hline \multicolumn{2}{c}{ Kultivar } & \multicolumn{3}{c}{ Auksin $(0,25 \mathrm{ppm})$} & \multicolumn{2}{c}{ Konsentrasi Sukrosa } \\
\hline DTO-28 & $3,66 \mathrm{a}$ & IAA & 3,31 & $\mathrm{a}$ & $90 \mathrm{~g} / 1$ & $4,97 \mathrm{a}$ \\
Desiree & $2,49 \mathrm{~b}$ & IBA & $1,93 \mathrm{~b}$ & $120 \mathrm{~g} / 1$ & $2,78 \mathrm{~b}$ \\
& & NAA & 3,81 & $\mathrm{a}$ & $150 \mathrm{~g} / 1$ & $1,30 \mathrm{c}$ \\
\hline
\end{tabular}

Keterangan: Angka-angka yang diikuti oleh huruf yang sama pada kolom yang sama berarti berbeda tidak nyata berdasarkan uji $D M R T$ pada taraf $p=5 \%$.

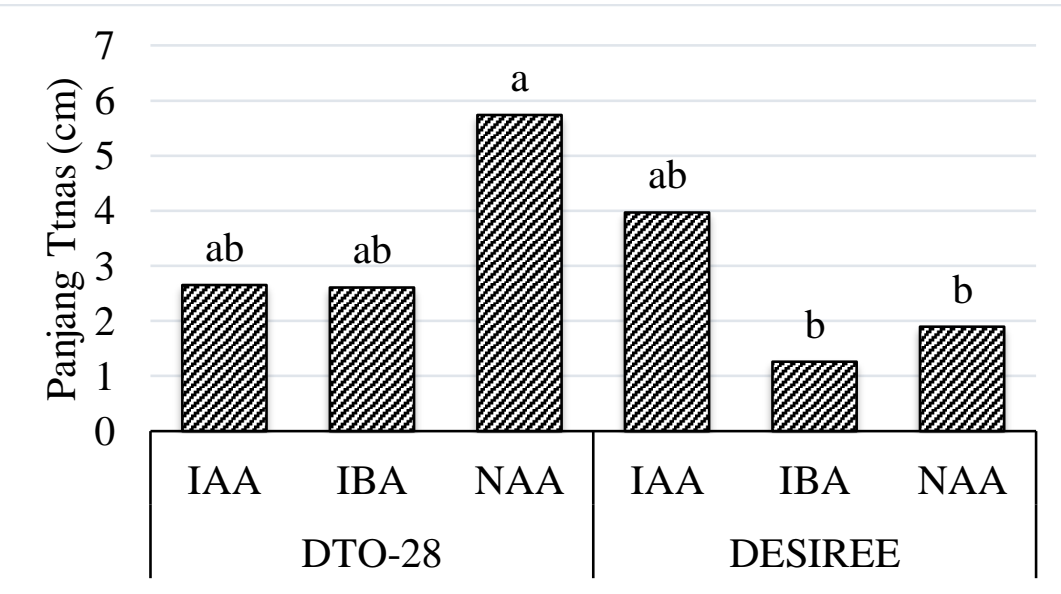

Keterangan: Angka-angka yang diikuti oleh huruf yang sama berarti berbeda tidak nyata berdasarkan uji $D M R T$ pada taraf $p=5 \%$.

Gambar 5. Grafik panjang tunas $(\mathrm{cm})$ hasil pengaruh interaksi antara kultivar dan auksin. 


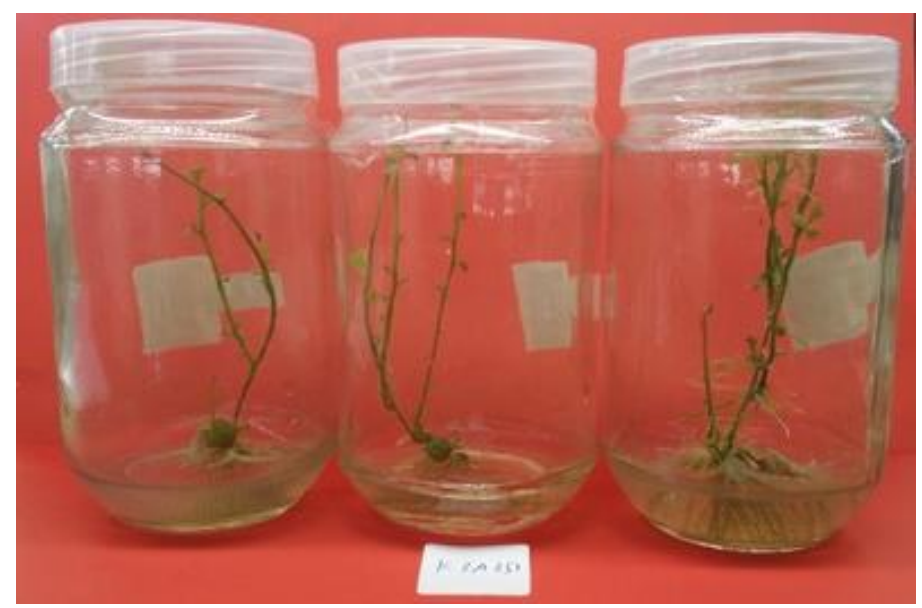

Gambar 6. Pertumbuhan tunas dan ubi mikro kultivar DTO-28 pada 1/2 MS+0,25 ppm NAA + $90 \mathrm{~g} / \mathrm{l}$ sukrosa.

memiliki pengaruh yang sama dalam memacu pemanjangan tunas dibandingkan IBA. Pemanjangan tunas dipengaruhi oleh auksin melalui dominasi apikal dan pemanjangan sel. Dominansi apikal terjadi karena auksin yang diproduksi pada bagian pucuk tunas ditransportasikan secara basipetal dan dapat menekan pertumbuhan tunas aksilar (Mani dan Hannachi, 2015). Konsentrasi sukrosa yang paling rendah (90g/l) ternyata lebih memacu pemanjangan tunas daripada konsentrasi yang lebih tinggi (Tabel 5). Diduga tekanan osmotik semakin meningkat pada media sehingga difusi nutrisi dan auksin menjadi terhambat untuk memacu pemanjangan tunas. Rahman et al. (2010), menyatakan bahwa konsentrasi gula yang tinggi dapat menyebabkan pemendekan ruas tanaman kentang.

\section{KESIMPULAN}

Kultivar DTO-28 lebih responsif dalam membentuk umbi atau tunas daripada Kultivar Desiree. Konsentrasi sukrosa berpengaruh terhadap pertumbuhan umbi mikro. Semakin tinggi konsentrasi sukrosa dapat meningkatkan persentase eksplan yang membentuk umbi. Umbi terbanyak dengan jumlah rata-rata 2,4 umbi/planlet, tumbuh pada media perlakuan $1 / 2 \mathrm{MS}+0,25$ ppm NAA + 150 g/l sukrosa. Selain itu, sukrosa juga berpengaruh terhadap pertumbuhan tunas, hal tersebut terlihat pada jumlah maupun panjang tunas yang dihasilkan. Jumlah tunas terbanyak $(5,27$ tunas/eksplan) dengan panjang rata-rata 4,70 cm mampu tumbuh pada media dengan penambahan $90 \mathrm{~g} / 1$ sukrosa. 


\section{UCAPAN TERIMA KASIH}

Peneliti mengucapkan terimakasih kepada Direktorat Riset dan Pengabdian Masyarakat (DRPM) Kementerian Riset, Teknologi, dan Pendidikan Tinggi yang telah mendanai penelitian ini.

\section{DAFTAR PUSTAKA}

Al-sulaiman, M.A. 2011. Variability in response of potato (solanum tuberosum ) cultivars to in vitro shoot regeneration. JKAU: Met., Env. \& Arid Land Agric. Sci., 22(2):3 - 20.

Damiri, A. and D. Sugandi. 2016. Pertumbuhan dan hasil kentang merah di dataran medium Kabupaten Rejang Lebong Bengkulu. Dalam D. Sugandi (Eds.) Prosiding Seminar Nasional Inovasi Teknologi Pertanian Modern Mendukung Pembangunan Pertanian Berkelanjutan. Bengkulu

Gaafar, K., A. Elaleem, R.S. Modawi, M.M. Khalafalla, and G. Engineering. 2015. Micro tuber induction of two potato (Solanum tuberosum L.) varieties namely, Almera and Diamant. International Research Journal of Biological Sciences, 4(3): $84-89$.

Handayani, T. and E. Sofiari. 2011. Karakterisasi morfologi klon kentang di dataran medium. Buletin Plasma Nutfah: 116 - 121 .

Kaur, M., R. Kaur, C. Sharma, N. Kaur, and A. Kaur. 2014. Effect of growth regulators on micro propagation of potato cultivars. Journal of Cell \& Tissue Research, 14 (2).

Koleva Gudeva, L., S. Mitrev, F. Trajkova, and M. Ilievski. 2012. Micropropagation of Potato Solanum tuberosum L. Electronic Journal of Biology, 8(3): 45 - 49.

Kumlay, A.M. and S. Ercisli. 2015. Callus induction, shoot proliferation and root regeneration of potato (Solanum tuberosum L.) stem node and leaf explants under long-day conditions. Biotechnology \& Biotechnological Equipment, 29(6):1075 - 1084.

Lachman, J., K. Hamouz, P. Dvořák, and M. Orsák. 2005. The effect of selected factors on the content of protein and nitrates in potato tubers. Czech Academy of Agricultural Sciences Agricultural Journal, 2005(1):431 - 438 .

Liao, J. 2011. The Role of Auxin Related Genes in the Initiation of Potato Tuber Formation. Wageningen University.

Mani, F. and C. Hannachi. 2015. Physiology of potato sprouting. Journal of New Sciences, 17.

Pasare, S.A., L.J.M. Ducreux, W.L. Morris, R. Campbell, S.K. Sharma, E. Roumeliotis, W. Kohlen, S. Van Der Krol, P.M. Bramley, A.G. Roberts, P.D. Fraser, M.A. Taylor, and M.A. Taylor. 2013. The role of the potato (Solanum tuberosum L.) CCD8 gene in stolon and tuber development. New Phytologist, 198: 1108 - 1120.

Purwanto, P., A.S.D. Purwantono, and S. Mardin. 2007. Modifikasi media ms dan perlakuan penambahan air kelapa untuk menumbuhkan eksplan tanaman kentang. Agrin: Jurnal Penelitian Pertanian, 11(1).

Rahman, M.H., R. Islam, M. Hossain, M.S. Islam, and others. 2010. Role of sucrose, glucose and maltose on conventional potato micropropagation. Journal of Agricultural Technology, 6(4): 733 739.

Romanov, G.A., N.P. Aksenova, T.N. Konstantinova, S.A. Golyanovskaya, J. Kossmann, and L. Willmitzer. 2000. Effect of indole-3-acetic acid and kinetin on tuberisation 
parameters of different cultivars and transgenic lines of potato in vitro. Plant Growth Regulation, 32(2): 245 $-251$.

Roumeliotis, E., B. Kloosterman, M. Oortwijn, W. Kohlen, H.J. Bouwmeester, R.G.F. Visser, and C.W.B. Bachem. 2012. The effects of auxin and strigolactones on tuber initiation and stolon architecture in potato. Journal of Experimental Botany, 63(12): 4539 - 4547.

Samadi, B. 2007. Kentang dan Analisis Usaha Tani. Yogyakarta: Kanisius.
Skrzypek, E., M. Szechy, Ŝ. Gra, and A. Goc. 2008. The role of osmotic stress during in vitro regeneration of Triticum aestivum L. Zeszyty Problemowe Postêpów Nauk Rolniczych, (3): 221 - 230.

Sonnewald, S. and U. Sonnewald. 2014. Regulation of potato tuber sprouting. Planta, An International Journal of Plant Biology, 239(1): 27 - 38.

$\mathrm{Yu}$, W.-C., P.J. Joyce, D.C. Cameron, and B.H. McCown. 2000. Sucrose utilization during potato microtuber growth in bioreactors. Plant Cell Reports, 19(4): 407 - 413. 